\title{
SELECTED COMBINED POWER SYSTEMS CONSISTED OF SELF- IGNITION ENGINE AND STEAM TURBINE
}

\author{
Wojciech Olszewski \\ Marek Dzida \\ Gdańsk University of Technology, Poland
}

\begin{abstract}
This paper presents optimization of selected combined diesel engine-steam turbine systems. Two systems: the system combined with waste heat one-pressure boiler only and its version containing additionally low-pressure boiler proper feeding degasifier and the system of two-pressure cycle, were taken into considerations. Their surplus values of power output and efficiency associated with utilization of waste heat contained in piston engine exhaust gas were compared to each other. For the considerations two high-power low-speed engines were taken into account. The main engines of comparable power of about $54 \mathrm{MW}$ produced by Wartsila and MAN Diesel \& Turbo firms, were selected.
\end{abstract}

Keywords: self-ignition engine, combined systems, steam turbine

\section{INTRODUCTION}

For many years in Polish economy the striving to improve efficiency of land and marine power plants has been observed. It results from economic conditions associated with varying level of fuel prices as well as ecological reasons ( the lower fuel consumption the lower emission of harmful substances to the atmosphere). Therefore new solutions are searched for in order to increase efficiency of driving systems by means of combining self-ignition engines with other thermal engines such as steam and gas turbines.

Heat contained in exhaust gas from self-ignition engine may be utilized for production of superheated steam feeding steam turbine. Such solution makes it possible to increase efficiency of the combined system without any additional fuel dose.

The most suitable engine for such systems is a low-speed, piston combustion engine fed with heavy fuel oil. Efficiency of such engines is contained within the range of $40-50 \%$. [10, 14].
At such high unit power outputs, in exhaust gases leaving the engine huge amounts of heat which may be utilized for production of steam used in steam turbine cycle, are contained. The heat is used for production of steam utilized in steam turbine cycle.

\section{IDENTIFICATION OF THE INVESTIGATION OBJECT}

In marine drives, combined diesel engine - steam turbine power systems are designed to increase thermodynamic cycle efficiency. In such system the steam turbine cycle is driven by water vapour produced in waste heat boiler fed with exhaust gas from diesel engine. The solution may be applied to ship propulsion as well as to a floating marine electric power station for production electric power in regions of a higher demand for electricity. Fig. 1 through 3 present concepts of combined diesel engine - steam turbine power systems. 


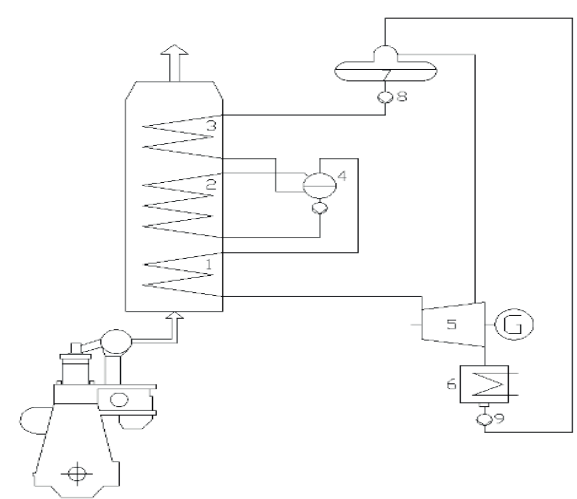

Fig. 1. Variant of a power system with one-pressure cycle Designations: 1. Steam superheater, 2. Boiler proper, 3.Economizer, 4. Boiler drum, 5. Steam turbine, 6. Condenser, 7. Degasifier, 8. Main feed-water pump, 9. Condenser pump.

Fig. 1 presents the simplest solution of the combined system, i.e. a steam cycle with waste heat one-pressure boiler. It comprises the waste heat boiler, steam condensing turbine, condenser, feed-water heater, as well as degasifier fed from steam turbine extraction. The boiler produces steam of one pressure value, in the turbine only one regeneration tap point for water heating is provided in the mixture heater degasifier. The waste heat boiler is composed of the three parts: - feed-water heater (economizer);

- boiler proper;

- steam superheater.

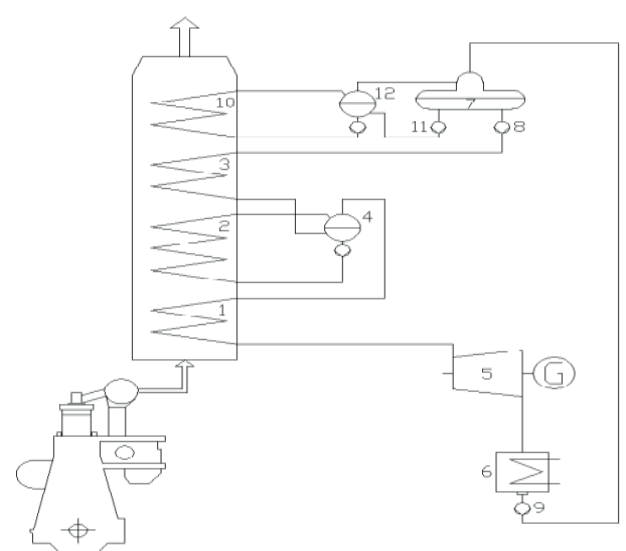

Fig. 2 Variant of a power system with one-pressure cycle containing additionally a low-pressure boiler proper to feed degasifier

Designations: 1. Steam superheater, 2. Boiler proper, 3.Economizer, 4. Boiler drum, 5. Steam turbine, 6. Condenser, 7. Degasifier, 8. Main high-pressure feed-water pump, 9. Condenser pump. 10. Low-pressure loop heater (of boiler proper), 11.Low-pressure pump, 12. Low-pressure boiler drum .

Fig. 2 presents a version of the cycle in which saturated vapour from the low-pressure boiler proper feeds degasifier of the steam system. As a result, amount of the power necessary to drive feed-water pump is low and constitutes only about $10 \%$ of power of the main feed-water pump.

Because it is two-phase flow, it is necessary to assure (during designing the piping) the flowing of water/ steam mixture into the boiler proper.

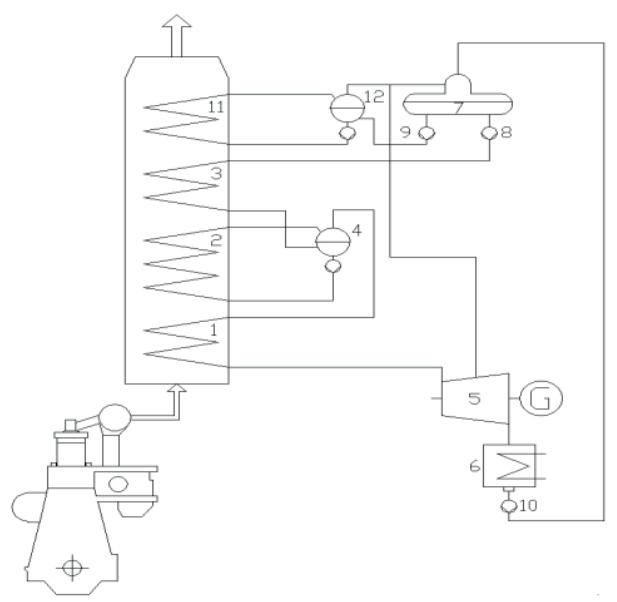

Fig. 3 A combine cycle composed of diesel engine and two-pressure waste heat boiler to feed steam turbine

Designations: 1. High-pressure superheater, 2. High-pressure boiler proper,

3. High-pressure economizer, 4. High-pressure boiler drum, 5. Steam turbine, 6. Condenser, 7. Degasifier, 8. High-pressure feed-water pump, 9. Low-pressure feed-water pump, 10. Condenser pump, 11. Low-pressure boiler proper, 12.Low-pressure boiler drum.

Fig. 3 presents the cycle fitted with two feed-water heaters. Such solution assures not only a better utilization of waste heat but also causes that use of low pressure improves thermodynamic properties of the cycle. Compared with onepressure cycle, an additional steam flux from low-pressure cycle feeds steam turbine.

To improve cycle thermodynamic properties it is advised to apply fuels of a low sulphur content. Such solution makes it possible to reach a low level of saturation point. It allows to utilize exhaust gas for heating feed water at a low temperature in feed-water heater. Optimum temperature and pressure parameters in the boiler proper allow to decrease amount of produced steam.

Combined systems comprising steam cycle should best utilize heat contained in exhaust gas from diesel engine. Therefore its optimization means determination of such values of steam cycle parameters for which steam turbine reaches maximum power. It is necessary to limit area of searching for optimum parameters to that for which the constraints imposed on the system in question are satisfied. Calculations of the combined system based on diesel engine were conducted for both one-pressure and two-pressure systems. Steam turbine cycles in combined systems were calculated for the same assumptions and parameters as in the case of constraints.

\section{THERMAL CALCULATIONS}

The proposed concept of the combined power system for ships as well as floating marine electric power station requires to perform energy balance evaluation for the analyzed cycle. The power output of the combined cycle of electric power plant was determined by summing particular power values of the system's elements ( i.e. diesel engine and steam turbine): 


$$
\begin{array}{r}
N_{\text {combi }}=N_{D}+N_{T P}= \\
=N_{D}\left(1+\frac{N_{T P}}{N_{D}}\right)
\end{array}
$$

On this basis, efficiency of the combined system was determined:

$$
\eta_{c o m b i}=\frac{N_{c o m b i}}{m_{f D} \cdot W u}=\eta_{D} \cdot\left(1+\frac{N_{T P}}{N_{D}}\right)
$$

where:

$$
\eta_{D}=\frac{N_{D}}{m_{f D} \cdot W u}
$$

as well as specific fuel consumption:

$$
b_{e_{\text {combi }}}=b_{e D} \cdot \frac{1}{\left(1+\frac{N_{T P}}{N_{D}}\right)}[\mathrm{g} / \mathrm{kWh}]
$$

Designations: $\mathrm{m}_{\mathrm{fD}}-$ fuel mass flux; $\mathrm{Wu}-$ fuel calorific value.

According to the formula (2) the addition of a steam cycle to the diesel engine cycle makes it possible to increase power output of the combined cycle and consequently its efficiency.

In combined steam turbine systems of a low live steam power and temperature one-pressure systems are used $[2,5,8]$, Fig. 1 . The application of one-pressure system does not guarantees to reach optimum utilization of energy contained in exhaust gas in case when its temperature is high. In such steam turbine systems a solution with another low-pressure boiler proper is most often applied [2,5], Fig. 2. It leads not only to increased utilization of waste heat contained in exhaust gas but also to better thermodynamic usage of lowpressure steam.

Numerical calculations of combined diesel engine-steam turbine systems were conducted for the two following lowspeed piston engines: Wartsila 9RTA96C diesel engine and MAN Diesel \& Turbo 9K98MC-C7.1-TII diesel engine, (Tab. 1).

\section{ASSUMPTIONS}

During analyzing any cycle a very important stage is consideration of its limitations which result both from strength, technical and lifetime conditions of particular elements of the system as well as from design and economic constraints.

Value of difference between exhaust gas temperature and live steam temperature for shipboard waste heat boilers was assumed equal to $\cdot t=10^{\circ} \mathrm{C}$ in accordance with the subject - matter literature [8,9]. Feed-water temperature in gasifier was assumed equal to todg $=\mathrm{twz}-2{ }^{\circ} \mathrm{C}$. The limit degree of steam dryness behind the steam turbine was assumed in the range of $x_{\text {limit }}=0,86-0,88$. For shipboard seawater - cooled condensers the MAN Diesel \& Turbo firm [5] recommends to assume the pressure in condenser, $\mathrm{p}_{\mathrm{k}}=0,065$ bar. Temperature of water feeding the boiler is of importance for lifetime of feedwater heater in the boiler. The MAN firm [9] recommends to assure feed-water temperature not lower than $120^{\circ} \mathrm{C}$, at its sulphur content not greater than $2 \%$. The limit temperature of exhaust gas from waste heat boiler tspal $>137^{\circ} \mathrm{C}$ (because of sulphur content in fuel) [7]. In the calculations the fuel calorific value was assumed constant and equal to $\mathrm{Wu}=42700$ $\mathrm{kJ} / \mathrm{kg}$, and the mechanical efficiency $\eta \mathrm{m}=0,98$.

The calculations of the combined system with diesel engines were conducted for one-pressure and two-pressure solutions in compliance with the assumed parameters of the engines in question.

Tab 1. Principal parameters of the selected diesel engines [11,14]

\begin{tabular}{|c|c|c|c|}
\hline Parameter & Unit & $\begin{array}{r}\text { 9RTA96C } \\
\text { WARTSILA }\end{array}$ & $\begin{array}{c}\text { 9K98MC-C7.1-TII MAN } \\
\text { DIESEL \& TURBO }\end{array}$ \\
\hline $\mathrm{ND}$ & $\mathrm{kW}$ & 46332 & 48762 \\
\hline $\mathrm{m}_{\mathrm{sD}}$ & $\mathrm{kg} / \mathrm{s}$ & 104,504 & 134,25 \\
\hline $\mathrm{m}_{f D}$ & $\mathrm{~kg} / \mathrm{s}$ & 2,146 & 2,369 \\
\hline $\mathrm{t}_{\mathrm{wyl}}$ & $\mathrm{oC}$ & 271 & 232,8 \\
\hline $\mathrm{b}_{\mathrm{eD}}$ & $\mathrm{g} / \mathrm{kWh}$ & 166,8 & 174,9 \\
\hline
\end{tabular}

\section{COMPARISON OF THE COMBINED SYSTEMS COMPRISING DIESEL ENGINE AND ONE OF THE SELECTED VARIANTS OF STEAM CYCLES}

For calculations of the combined diesel engine - steam turbine systems the two ship low-speed engines: Warstsila diesel engine [14] and MAN Diesel \& Turbo 9K98MC diesel engine [10] of similar power output were selected. The considerations were conducted for the combined system with steam turbine cycle comprising either one-pressure boiler acc. Fig. 1 or two-pressure boiler acc. Fig. 3. The calculations were done in accordance with producer's data for the reference point acc. ISO Conditions: Ambient air temperature of $25^{\circ} \mathrm{C}$ and Barometric pressure of 1 bar, Tab.1.

Results of the calculations for the presented combined diesel engine - steam turbine systems can be found in the publication [7] where algorithm of the calculations was also described in detail.

Results of the performed numerical calculations are presented in a graphical form showing the statement of: steam turbine power output in function of live steam pressure, efficiency of the combined cycles in function of live steam pressure as well as temperature of exhaust gas from waste heat boiler in function of live steam pressure as well as temperature in degasifier.

The combined systems are marked as follows: Ob_I - comprising one-pressure waste heat boiler; Ob_II - comprising one-pressure waste heat boiler and additional low-pressure boiler proper feeding degasifier; 
Ob_III_1- with two-pressure cycle $\left(\mathrm{pI}=1,05^{\star} \mathrm{p}_{\mathrm{odg}}\right)$;

Ob_III_2 - with two-pressure cycle $\left(\mathrm{pI}=1,5^{*} \mathrm{p}_{\text {odg }}\right)$.

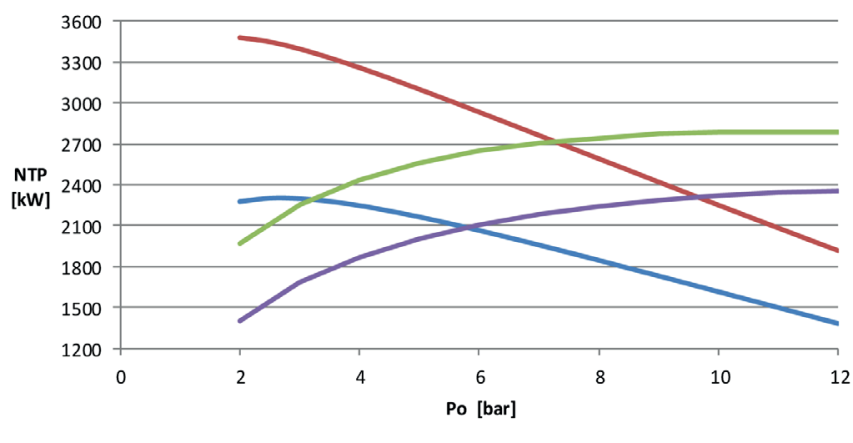

- Ob_I Ob_II - Ob_III_1 Ob_III_2

Fig. 4 Steam turbine power output in function of live steam pressure as well as the feed-water temperature in degasifier todg $=150{ }^{\circ} \mathrm{C}$, for $9 \mathrm{~K} 98 \mathrm{MC}$ engine

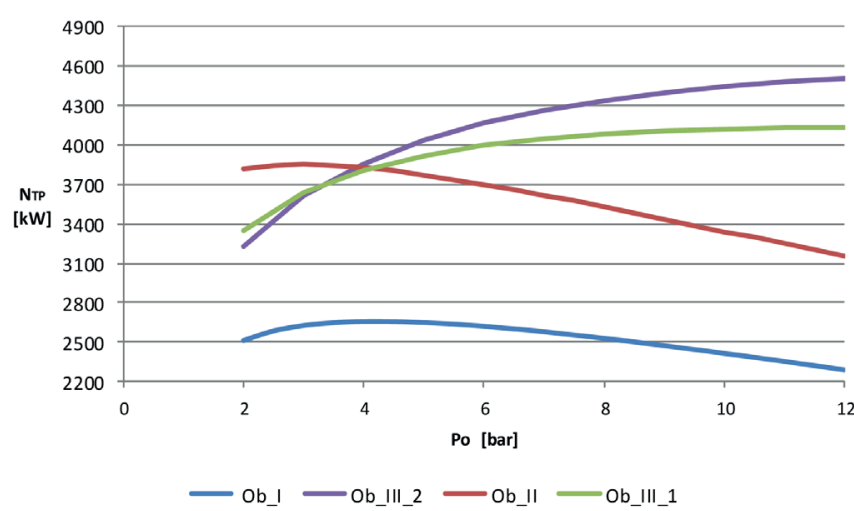

Fig. 5 Steam turbine power output in function of live steam pressure as well as the feed-water temperature in degasifier, todg $=150^{\circ} \mathrm{C}$, for $9 R T A 96 \mathrm{C}$ engine

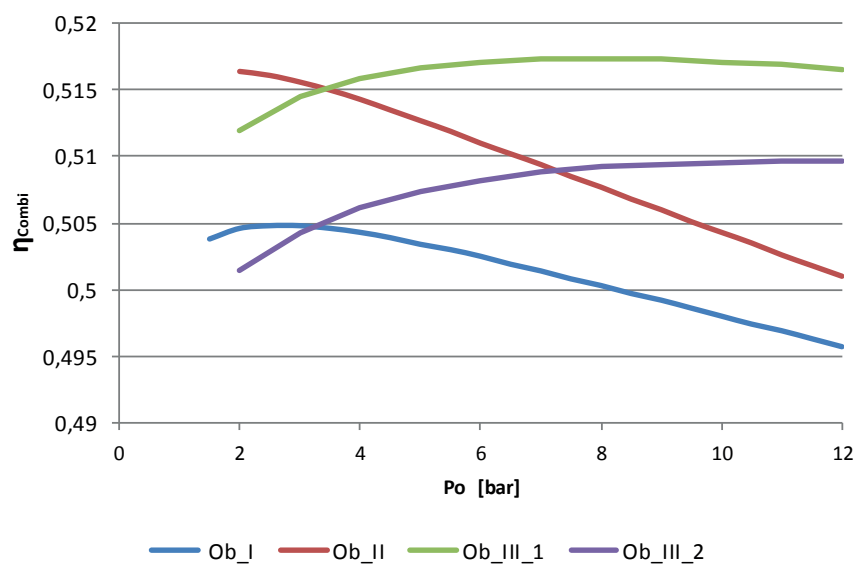

Fig. 6 Efficiency of the combined systems in function of live steam temperature as well as feed-water temperature in degasifier, todg $=150^{\circ} \mathrm{C}$, for 9 K98MC engine

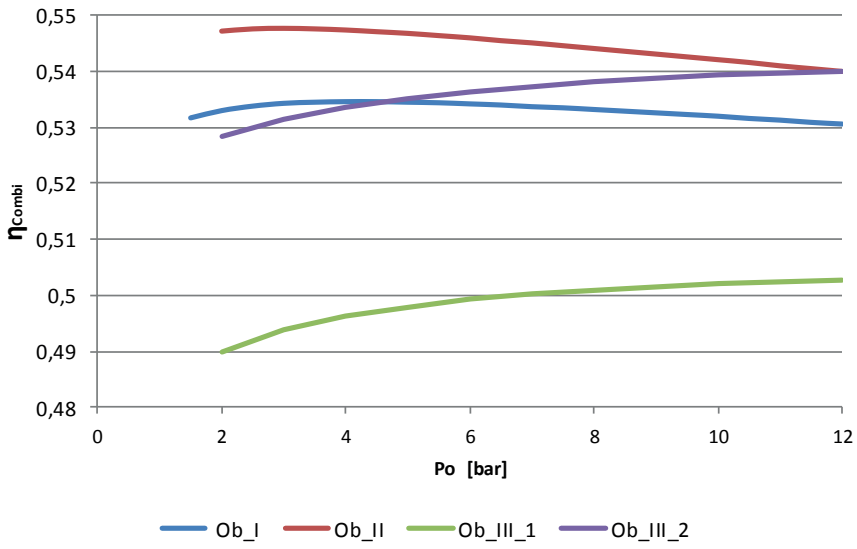

Fig. 7 Efficiency of the combined systems in function of live steam temperature as well as feed-water temperature in degasifier, todg $=150{ }^{\circ} \mathrm{C}$, for 9RTA96C engine

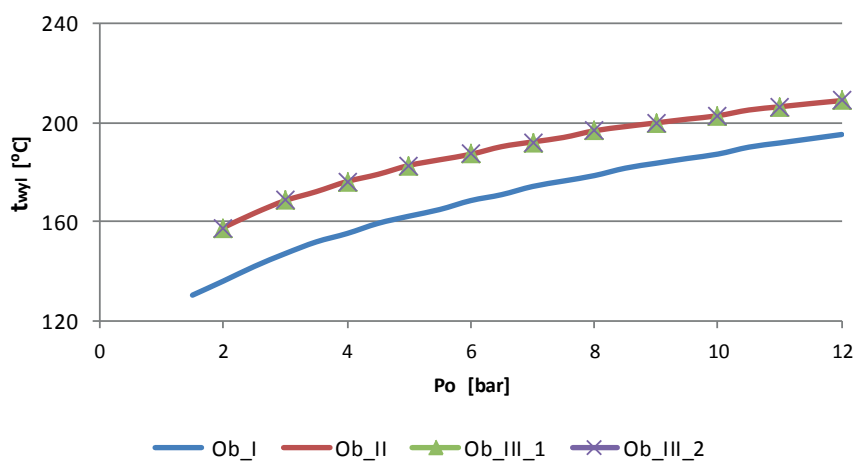

Fig. 8 Temperature of exhaust gas from waste heat boiler in function of live steam pressure as well as the feed-water temperature in degasifier. todg $=150^{\circ} \mathrm{C}$, for $9 \mathrm{~K} 98 \mathrm{MC}$ engine

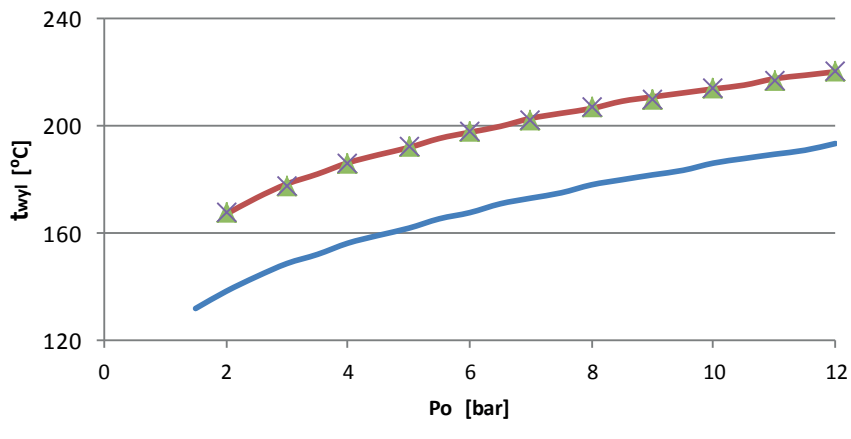

$\longrightarrow$ Ob_I - Ob_II $\leftarrow$ Ob_III_ $\leftarrow$ Ob_III2

Fig. 9 Temperature of exhaust gas from waste heat boiler in function of live steam pressure as well as the feed-water temperature in degasifier, todg $=150{ }^{\circ} \mathrm{C}$, for 9 RTA $96 \mathrm{C}$ engine

Tab. 2 shows calculation results for the analyzed combined cycles compared with those for two low-speed piston engines: 9RTA96C and 9K98MC-C7.1-TII alone. 
Tab. 2 Parameters of the combined diesel engine - steam turbine systems

\begin{tabular}{|c|c|c|c|c|c|c|c|c|c|}
\hline Parameter & Unit & \multicolumn{4}{|c|}{ 9RTA96C } & \multicolumn{4}{|c|}{ 9K98MC-C7.1-TII } \\
\hline ND & $\mathrm{kW}$ & \multicolumn{4}{|c|}{46332} & \multicolumn{4}{|c|}{48762} \\
\hline$\eta_{\mathrm{D}}$ & $\%$ & \multicolumn{4}{|c|}{50,56} & \multicolumn{4}{|c|}{48,2} \\
\hline $\mathrm{t}_{4}$ & ${ }^{\circ} \mathrm{C}$ & \multicolumn{4}{|c|}{271} & \multicolumn{4}{|c|}{232,8} \\
\hline$t_{w z}$ & ${ }^{\circ} \mathrm{C}$ & \multicolumn{4}{|c|}{151,8} & \multicolumn{4}{|c|}{152} \\
\hline t0 & ${ }^{\circ} \mathrm{C}$ & \multicolumn{4}{|c|}{261} & \multicolumn{4}{|c|}{222,8} \\
\hline & & Ob_I & Ob_II & Ob_III_1 & Ob_III_2 & Ob_I & Ob_II & Ob_III_1 & Ob_III_2 \\
\hline NTP & $\mathrm{kW}$ & 2656 & 3855 & 4588 & 3157 & 2301 & 3479 & 2786 & 2349 \\
\hline Po & bar & 4 & 3 & 12 & 12 & 2,5 & 2 & 11 & 12 \\
\hline $\mathrm{x} 2$ & & 0,9223 & 0,9005 & 0,8149 & 0,8157 & 0,9258 & 0,9052 & 0,8033 & 0,7948 \\
\hline NTP / ND & $\%$ & 5,73 & 8,32 & 9,9 & 6,81 & 4,73 & 7,18 & 5,71 & 4,82 \\
\hline$\eta_{\text {Combi }}$ & $\%$ & 53,46 & 54,77 & 50,26 & 54,01 & 50,48 & 51,64 & 50,96 & 50,53 \\
\hline
\end{tabular}

The performed calculations was aimed at determination of optimum parameters of the analyzed combined cycles comprising diesel engine and steam turbine in case of application of two types of diesel engines.

From the analysis of steam cycle calculations of the considered combined systems of ship power plant results that maximum power developed by the steam turbine reaches, depending on a diesel engine, percentage value of $9,9 \%$ and $7,18 \%$ in relation to power of piston engine alone. The higher value of combined system efficiency is achieved in case of the system with 9RTA96C engine compared with that comprising 9K98MC-C7.1-TII engine.

The performed numerical calculations of the analyzed combined diesel engine - steam turbine cycle allow to formulate the following conclusions:

- Without any additional fuel dose it is possible to increase the power output from the combined system comprising 9RTA96C diesel engine by $9,9 \%$ and $7,18 \%$ for that with 9K98MC-C7.1-TII diesel engine in relation to the conventional power plant;

- Owing to application of a combined power plant it is possible to increase energy efficiency of power plant for optimum parameters of 9RTA96C diesel engine - up to $54,77 \%$, and up to $51,64 \%$ for optimum parameters of 9K98MC-C7.1-TII diesel engine.

\section{FINAL CONCLUSIONS}

It is possible to apply a combined system composed of diesel engine and steam turbine cycle which utilizes waste heat contained in exhaust gas. Such systems reach higher thermodynamic efficiency due to utilization of waste heat contained in exhaust gas without any need of supplying additional fuel dose.
The performed numerical calculations of the analyzed combined diesel engine - steam turbine system made it possible to state:

- an increase in energy efficiency of power plant at optimum parameters due to application of a combined power plant;

- an increase in power output of combined power plant in relation to conventional one without application of any additional fuel dose;

- possible application of diesel engine of a lower output in view of possibility to increase it by applying a combined system with steam turbine.

In this work only thermodynamic analysis of ship power plants was performed without necessary additional technical - economical analysis which could fully justify application of such system to ship power plants.

\section{BIBLIOGRAPHY}

1. ABB ALSTOM POWER Ltd. Gas Turbine and CombinedCycle Power Plants, Switzerland, CH-50 5401, Baden

2. Dzida M: Possible Efficiency Increasing of Ship Propulsion and Marine Power Plant with the System Combined of Marine Diesel Engine, Gas Turbine and Steam Turbine. A chapter in the book on Advances in Gas Turbine Technology edited by Dr Ernesto Benini. ( ISBN 978-953307-611-9.) INTECH, 2011

3. Altosole, M.; Benvenuto, G.; Campora, U.; Laviola, M.; Trucco, A.: Waste Heat Recovery from Marine Gas Turbines and Diesel Engines. Energies 2017, 10, 718

4. Chmielniak T.: Thermodynamic cycles of thermal turbines (in Polish). PAN, Gdańsk 1988 
5. Dzida M.: On the possible increasing of efficiency of ship power plant with the system combined of marine diesel engine, gas turbine and steam turbine at the main engine - steam turbine mode of cooperation. Polish Maritime Research, Vol. 16, No.1(59), (2009), pp. 47-52, ISSN 1233-2585

6. Dzida, M., Dzida, S., Girtler, J.: On the possible increasing of efficiency of ship power plant with the system combined of marine Diesel engine, gas turbine and steam turbine in case of main engine cooperation with the gas turbine fed in series and the steam turbine, Polish Maritime Research, No. 3 (61), Vol. 16, pp. 26-31, 2009

7. Dzida, M., Olszewski, W.: Comparing combined gas turbine/steam turbine and marine low speed piston engine/steam turbine systems in naval applications, Polish Maritime Research, Vol. 18, No. 4(71), pp. 43-48, 2011

8. Kehlhofer R.:Combined-Cycle Gas \& Steam Turbine Power Plants, The Fairmont Press, INC., ISBN 0-88173-076-9, USA, 1991

9. MAN B\&M:The MC Engine. Exhaust Gas Date. Waste Heat Recovery System. Total Economy, MAN B\&W Publication S.A., Denmark, 1985

10. MAN Diesel \& Turbo \& Turbo: Stationary Engine. Programme, 4 th edition. Branch of MAN Diesel \& Turbo \& Turbo SE, Germany, Available from www.mandieselturbo. com, 2010

11. Olszewski, W.: Possible use of combined diesel engine/ steam turbine in ship power plant, Zeszyty Naukowe, Szczecin Maritime University, Vol. 28(100), No. 1, pp. 8894, 2011

12. Olszewski W., Dzida M.: Issues of economic analysis of electric energy generation in a floating power plant. Journal of Polish CIMAC, Vol. 9, No. 1 (2014), pp.103-110

13. Perycz S.: Steam and gas turbines (in Polish). Publishing House of Gdańsk University of Technology, Gdańsk 1988

14. Sulzer RTA 96C: Engine Selection and Project Manual, Wartsila, June 2001

15. Wajand J.A.: Self-ignition engines ( Diesel engines) (in Polish). WN-T, Warszawa 1980.

\section{CONTACT WITH THE AUTHORS}

\author{
Wojciech Olszewski \\ Marek Dzida \\ Faculty of Ocean Engineering and Ship Technology \\ Gdańsk University of Technology \\ 11/12 Narutowicza St. \\ 80-950 Gdańsk \\ Poland
}

